\title{
ATTRIBUTION TENDENCY AND ITS RELATIONSHIP WITH IRANIAN EFL STUDENTS' LEARNING STYLE AT ADVANCE LEVEL, A STRUCTURE EQUATION MODELING APPROACH
}

\author{
Khalil Motallebzadeh \\ Department of English, Torbat-e Heydarieh Branch, Islamic Azad University, Torbat-e Heydarieh, Iran \\ *Maryam Ebrahimi Seresht (Corresponding author) \\ Department of English, Torbat-e Heydarieh Branch, Islamic Azad University, Torbat-e Heydarieh, Iran \\ Samaneh Ardalan Javan \\ Department of English, Torbat-e Heydarieh Branch, Islamic Azad University, Torbat-e Heydarieh, Iran
}

\begin{abstract}
This study was designed to find out whether there is any association between EFL learners attribution tendency and their learning style level at advance level. To this end 135 English learners were chosen as the subject of the study; 85 female, and 50 male. They were asked provide answers to two valid, reliable questionnaires; attribution questionnaire (ATFLL), and Reid's (1987) PLSP Questionnaire. Having obtained the raw data, the SPSS software (version 21) was used to change the data into numerical interpretable form. Then, the correlation between the subscales of two variables was calculated. Also structure equation model was run. The result of the study indicated that there is high, positive correlation between Kinesthetic learning style and internal attribution. Moreover, Individual learning style had the highest positive correlation while group learning had the highest negative correlation with external attribution.
\end{abstract}

KEYWORDS: ATTRIBUTION THEORY, LEARNING STYLE, ADVANCE LEVEL, EFL

\section{Introduction}

Attribution theory stemmed from the field of social psychology that defines the way certain people describe the reasons of events, their own behavior and other people's behavior. Heider (1958) is mainly recognized to have laid the basis for attribution theory. He considers that the way in which people recognize or think about events has a much more significant influence on their behavior than what really occurred and relates this to the reasons for success and failure. He theorizes that people frequently refer to a fixed group of external reasons (situation, environmental) and internal factors (dispositional, within themselves) when they are asked about the reason of definite events or behavior occurred.

Weiner $(1974,1986)$ later developed on Heider's site, identifying skill, attempt, task difficulty, and luck as the most important achievement attributions. In addition, result might also be attributed to a number of additional issues including other people (such as teachers or other students), disposition, tiredness or sickness, character, and physical 


\section{A COMPARATIVE AND ANAIYTIC COMPARISON OF THE VARIOUS IMAGES OF MOON AND THE SUN BASED ON ANCIENT ASTRONOMY IN NASER KHOSRO, ANVARI AND NEZAMI'S POEMS}

appearance (Weiner, 1986). He categorized these attributions into three causal dimensions: locus of control, stability, and controllability," In the dimension of locus, an ending can be described as either internal or external; in the dimension of stability, the outcome is either stable or unstable (whether the causes change over time or not); and in the dimension of control, an outcome is either controllable or uncontrollable". Weiner (1986) further assumed that people attribute their successes and failures, and those of other individuals, according to the different combinations of the six elements stated above. Each of these causal elements affects individuals' expectancies for success, and has significant affective results.

Attribution theory is not just a "scientific conception" but rather a "field of study" which concerns with how people respond their "why" questions such as "why did I fail my exam?" and also the result of "causal beliefs" in their success and failure (Weiner \& Craighead, 2010, p.184). Foreign language learners face these "why" questions very frequently in the process of learning and they try to answer them in diverse means. Individuals will view these attributions from different perspectives (Dörnyei, 2003). In other words, each learner with his individual dissimilarity, insight, and the situation in which he is, relates his learning ability or inability to different factors. The wide varieties of learners' attributions could refer back to their personality type which is specific to each individual, so learners' personality traits may help or hinder the process of their language learning. Furthermore, as Williams and Burden (1997) proposed, in the domain of language learning the investigation of how learners perceive themselves and what effect personal assembles have upon the process of learning is supportive for teachers to assist the individuals.

Some researchers (e.g., Kalaja, 2004; Heikinnen, 1999; Hsieh \& Schallert, 2008; Tse, 2000; Williams \& Burden, 1999; Williams, Burden, \& Al-Baharna, 2001) had effort to investigate the subject of attribution theory and second language achievement. However, most of the existing studies have discovered a very wide range of attributions using qualitative methods, and offer mixed results. Consequently, more quantitative studies need to be carried out to offer novel insights and a more convincing and established findings on attribution theory and second language acquisition.

In the last three decades, an imperative transfer has been taken place in the field of second/foreign language teaching and learning, and researchers have focused mainly on learners' individual factors. O' Malley and Chamot (1990) point out that, "Differences between more effective learners and less effective learners were found in the number and range of strategies used". In addition, there is a relationship between the common utilization of learning strategies and achievement in the language (Green \& Oxford, 1995). According to Oxford (1990) learning strategies are "...specific actions taken by the learner to make learning easier, faster, more enjoyable, more self-directed, more effective, and more transferable to new situations" (p. 8). She emphasized, “...learning strategies are important for language learning because they are tools for active, self-directed involvement" (p. 1). Additionally, researchers have found that successful language learners are more likely to engage in active language learning and use more learning 


\section{A COMPARATIVE AND ANAIYTIC COMPARISON OF THE VARIOUS IMAGES OF MOON AND THE SUN BASED ON ANCIENT ASTRONOMY IN NASER KHOSRO, ANVARI AND NEZAMI'S POEMS}

strategies than less successful learners (Bialystok, 1981; Chamot \& Küpper,1989; Oxford \& Nyikos, 1989; Peacock \& Ho, 2003).

Among dominant issues in learning success, lots of researches have focused on learning styles (e.g., Oxford, 1995; Oxford \& Anderson, 1995; Reid, 1995, Wintergerst, DeCapua, Itzen, 2001), and possible relationships between learning styles and strategies (e.g., Carson \& Longhini, 2002; Ehrman, Leaver, Oxford, 2003; Ehrman \& Oxford, 1990).

Styles, as a general term, can be defined as "an individual's natural, habitual, and preferred way of absorbing, processing, and retaining new information and skills" (Kinsella, 1995, p. 171).

Learning styles are in general constant constructs that are developed by students despite of the topic being studied or the skill being mastered. There are different ways of categorizing styles.

Christison (2003) distinguishes between cognitive style (field dependent versus field independent, analytic versus global, reflective versus impulsive); sensory style (visual versus auditory versus tactile versus kinesthetic) and personality styles (tolerance of ambiguity, right brain versus left brain dominance).

Willing (1994) distinguished four chief styles: communicative, analytical, authority-oriented and concrete. These styles were derived from learner strategy preferences, which Willing (1994) clustered them in the following ways:

Communicative: These learners were described by the following learning strategies: they like to learn by watching, listening to native speakers, talking to friends in English, watching television in English, using English out of class, learning new words by hearing them, and learning by conversation.

Analytical: These learners like studying grammar, studying English books and newspapers, studying alone, finding their own mistakes, and working on problems set by the teacher.

Authority-oriented: The learners prefer the teacher to clarify everything, having their own textbook, writing everything in a notebook, studying grammar, learning by reading, and learning new expressions by seeing them.

Concrete: These learners tend to like games, pictures, film, video, using cassettes, talking in pairs, and practicing English outside class.

It seems that the relationship between learners' learning styles and their attributional factors not been studied to date. Thus, according to the gaps in the previous studies and few number of researches that take into account attribution theory in the field of language learning, and the significance of this theory (Dörnyei, 2005), what qualities the language learners have leads them to attributing to different factors needs to be further established. The present study

Is aimed to explore the relationship between attribution theory and learning styles among Iranian EFL learners.

\section{Review of the related literature}

Williams, Burden and Al-Baharna (2001) for example, revealed 11 positive and 18 negative attributions among 25 students learning English in Bahrain. They found that the chief attributions for success comprised practice, support from family, and a positive attitude, while the most common negative attributions include teaching methods, lack of support from family and teachers, weak understanding, and an undesirable attitude. In a further study on foreign 


\section{A COMPARATIVE AND ANAIYTIC COMPARISON OF THE VARIOUS IMAGES OF MOON AND THE SUN BASED ON ANCIENT ASTRONOMY IN NASER KHOSRO, ANVARI AND NEZAMI'S POEMS}

language learning among 285 adolescent students in the UK, Williams, Burden, Poulet and Maun (2004) identified 21 attribution categories, with the major reasons for doing well cited as effort, strategy, ability, teacher, interest, task, and peers. They also found that the majority of attributions for both success and failure were considered internal.

On the other hand, as a result of interviews with L2 learners of French, Williams and Burden (1999) discovered that the British primary school children attributed success to external factors, and many of the attributions mentioned were strongly connected to teacher influence.

Learning strategies enable students to take more responsibilities of their own language learning and expand autonomy in their studies. In other words, "Learners' practical involvement to enhancing the effectiveness of their own learning" (Dörnyei, 2005, p. 166) is necessary in developing skills in learning-how-to-learn. In organizing language strategies, Oxford (1990) makes a difference between direct and indirect strategies. Direct strategies are those exact processes that learners can employ to advance their language skills, and include memorizing, analyzing, reasoning and guessing intelligently. On the other hand, indirect strategies include factors such as evaluating one's learning and cooperating with others.

There have been many efforts to improve students' academic achievements. It has always been the chief concern of many dedicated instructors and parents that their pupils and children be as much successful as possible. To this end, many teachers are persuaded that students want the positive attitude to succeed academically. Often, one's learning style is identified to define strengths for academic achievement. Dunn, Beaudry and Klavas (1989) declare that through ample studies, it has been proved that both low and average achievers get higher scores on standardized achievement and attitude tests when they are trained within the category of their learning styles.

Q1: is there any significant relationship between Attribution tendency and Iranian EFL students' learning style at upper intermediate level?

\section{Research hypothesis}

Based on the research question the following null hypothesis was proposed:

H01: There is no significant relationship between Attribution tendency and its relationship with Iranian EFL students' learning style at upper intermediate level?

\section{Methodology}

\section{Participants and Setting}

This study was carried out in English different English language institutes in Mashhad. The sample consisted of 135 Iranian EFL language students, who were homogenized by the institute as they were studying at certain level. They were both males and females from different age groups, having spent more than eight years studying English. 


\section{A COMPARATIVE AND ANAIYTIC COMPARISON OF THE VARIOUS IMAGES OF MOON AND THE SUN BASED ON ANCIENT ASTRONOMY IN NASER KHOSRO, ANVARI AND NEZAMI'S POEMS}

In the present study, samples were randomly taken to meet condition that no specific requirements needed and thus, every individual had similar chance to become sample.

\section{Instrumentation}

To conduct the study, the following instruments were employed:

\section{Proficiency test}

In order to check EFL learners' language proficiency at advance level, a sample IELTS test of TOEFL was administered to the participants. They were assured that the result of the test would be kept secure.

\section{Attribution questionnaire (ATFLL)}

In order to test learners' attributional factors ATFLL Questionnaire was used. The inventory was developed by Pishghadam and Modarresi (2008), this questionnaire is the only validated device intended to consider the factors to which the learners attribute their successes and failures in the process of learning English as a foreign language. In ATFLL questionnaire the four factors of ability, effort, luck, and task difficulty, which Weiner (1979) had suggested as the sets of attribution, were given new labels of Emotions, Self-image, Intrinsic Motivation, and Language Policy. The number of items for every factor is as follows: the first factor consists of 9 items, the second factor 11 items, the third factor 6 items, and the fourth factor 4 items. This 30-item inventory is in the 5-point Likert-type scale with "strongly agree" at one end and "strongly disagree" at the other and it was written in Persian language. The reported reliability was 0.84 and in this study the reliability of the whole items (i.e. 30 items) estimated by Cronbach's Alpha was 0.80 .

\section{Learning style questionnaire}

The learning style inventory used in this study was a 30-item questionnaire developed by Reid (1987). In this questionnaire students were expected to state how they preferred to learn the language, for instance, whether they prefer working in groups, pairs, or individually. This questionnaire was used to assess the learners' learning styles preferences that can be classified into six chief learning styles: visual, tactile, auditory, group, kinesthetic, and individual learning style. Each item in the questionnaire discovers a specific learning style. In this questionnaire students were asked to mention whether they are strongly agree, agree, undecided, disagree or strongly disagree with the statements. The maximum score for each item is 25 .

\section{Procedure}

The study was conducted in English language institutes in Mashhad among 200 Iranian EFL students, studying at advance level. They were all randomly selected. Then, a sample IELTS test was administrated to them in order to find those with advance level. Finally, having calculated the results and eliminating those that were not proficient 


\section{A COMPARATIVE AND ANAIYTIC COMPARISON OF THE VARIOUS IMAGES OF MOON AND THE SUN BASED ON ANCIENT ASTRONOMY IN NASER KHOSRO, ANVARI AND NEZAMI'S POEMS}

enough 135 students; 85 females, and 50 males were selected. Then, the two questionnaires were spread to subjects of the research. After all papers containing answers from respondent were returned, they were ready to be calculated. To get a clear insight about the relationship between variable under study first correlation was conducted among six sub-constructs of learning style and internal and external attribution. Than Structural equation model was used.

\section{Results}

Descriptive statistics and correlations between six sub-constructs of Perceptual learning style preference questionnaire (Auditory, Visual, Tactile, Kinesthetic, Individual and group), two main sub-constructs of Attribution questionnaire (Internal and External) are given in Table 1.

As can be seen in Table 1, among six sub-constructs of Perceptual learning style preference Kinesthetic had the highest positive correlation $(\mathrm{r}=-.59, \mathrm{p}=.00)$ and Individual had the highest negative correlation $(\mathrm{r}=-.42, \mathrm{p}=.00)$ with internal. Moreover, Individual had the highest positive correlation $(r=-.57, p=.00)$ and group had the highest negative correlation $(\mathrm{r}=-.47, \mathrm{p}=.00)$ with external attribution. It was shown that students attributed their success and failure more often to external factors $(M=3.01)$ and less often to internal factors $(M=2.20)$. Furthermore, among the six sub-constructs of Perceptual learning style Auditory had the highest mean score (4.34) and group had the lowest mean score (2.22).

Table 1.

Descriptive statistics and correlation

$\begin{array}{lllllllll}\text { Mean (SD) } & 1 & 2 & 3 & 4 & 5 & 6 & 7 & 8\end{array}$

\begin{tabular}{lllllllllll}
\hline 1. Auditory & $4.34(1.02)$ & 1.00 & & & & & & & \\
2. Visual & $3.98(0.75)$ & $.45^{* *}$ & 1.00 & & & & & & \\
3. Tactile & $3.19(.85)$ & $.23^{*}$ & $.34^{* *}$ & 1.00 & & & & & \\
4. Kinesthetic & $3.11(1.07)$ & $.37^{* *}$ & $.42^{* *}$ & $.65^{* *}$ & 1.00 & & & & \\
5. Individual & $3.97(0.45)$ & $.29^{* *}$ & $.39^{* *}$ & .12 & .09 & 1.00 & & & \\
6. group & $2.22(0.99)$ & .11 & $.21^{* *}$ & $.35^{* *}$ & $.37^{* *}$ & $-.43^{* *}$ & 1.00 & & \\
7.Internal & $2.20(0.77)$ & .10 & .18 & $.25^{* *}$ & $.59^{* *}$ & $-.42^{* *}$ & $.55^{* *}$ & 1.00 & \\
8.External & $3.01(.95)$ & .16 & .13 & $.20^{*}$ & $-.39^{* *}$ & $.57^{* *}$ & - & $-.40^{* *}$ & 1.00 \\
\hline **Con & & & & & & & & $.47^{* *}$ & & \\
\hline
\end{tabular}

**Correlation is significant at the level of 0.01

${ }^{*}$ Correlation is significant at the level of 0.05 


\section{A COMPARATIVE AND ANAIYTIC COMPARISON OF THE VARIOUS IMAGES OF MOON AND THE SUN BASED ON ANCIENT ASTRONOMY IN NASER KHOSRO, ANVARI AND NEZAMI'S POEMS}

In order to have a better understanding of the role of six sub-constructs of Perceptual learning style on internal and external attributions, Structural Equation Modeling (SEM) was used. Figure 1 indicates the interrelationship among six sub-constructs of Perceptual learning style, internal and external attributions.



Figure 1. Interrelationship among six sub-constructs of Perceptual learning style, internal and external attributions

As indicated in Figure 1, among six sub-constructs of Perceptual learning style, group $(\beta=.37, p<0.05)$, tactile $(\beta=.18, \mathrm{p}<0.05)$ and kinesthetic $(\beta=.35, \mathrm{p}<0.05)$ positively and significantly and individual $(\beta=-.21, \mathrm{p}<0.05)$ negatively and significantly predict students' internal attributions. Moreover, individual $(\beta=.48, \mathrm{p}<0.05)$ positively and significantly, and group $(\beta=-.24, \mathrm{p}<0.05)$, and kinesthetic $(\beta=-.27, \mathrm{p}<0.05)$ negatively and significantly predict students' external attributions. To fit the model, non-significant paths were removed.

A number of fit indices were examined to evaluate the model fit. As the model shows, among all the fit indices, CFI (.91), GFI (.95), NFI (.92), the chi-square/df ratio (2.770), RMSEA (.099), RMSEA did not lie within the 


\section{A COMPARATIVE AND ANAIYTIC COMPARISON OF THE VARIOUS IMAGES OF MOON AND THE SUN BASED ON ANCIENT ASTRONOMY IN NASER KHOSRO, ANVARI AND NEZAMI'S POEMS}

acceptable fit thresholds based on Schreiber, Nora, Stage, Barlow, and King (2006). Hence, the model showed acceptable fit indices with the data.

\section{Discussion}

The present study sought to explore the relationship between EFL students' attribution tendency and their learning style. The findings of the study revealed that there is high, positive correlation between Kinesthetic learning style and internal attribution. Moreover, Individual learning style had the highest positive correlation while group learning had the highest negative correlation with external attribution.

EFL learners have definite perceptions of their learning and these ideas are under the influence of several elements like individual differences and learning styles. Accordingly, the findings of the current study can raise awareness in both language teachers and learners about avoidance of incorrect, constant, and intense attributions which may result in negative attitudes toward learning English. If language learners' perception of their success and failure in the process of learning is improper, it will have a direct influence on their future efforts. As Dörnyei (2001) states "we learn best when we expect success" (p.57). The outcomes of this research can also come in handy for investigators in the practice of Attribution Retraining. Learners' subjective clarifications of the consequence and findings of their learning play a significant role when they begin planning their future actions. Hence, in reattribution process the investigators should take into account various features which have control over these incorrect attributions to raise the possibilities of more future success and less repeated failure because of improper attitude toward learning.

\section{Conclusion}

The present study aimed to find out the between EFL learners attribution tendency and their learning style level at advance level. 135 English learners participated as the subject of the study. They were 85 female, and 50 male studying at advances level. The result of the study indicated that there is high, positive correlation between Kinesthetic learning style and internal attribution. Moreover, Individual learning style had the highest positive correlation while group learning had the highest negative correlation with external attribution.

Learners' attribution can be influenced by several different factors; thus, many other researches related to the same topic can be conducted so that factors other than learning style are taken into account. The data of this study were gathered from advanced learners aged from 18 to 30. It is suggested that different age groups with different proficiency levels be included in the replications. The same study can be carried out in situations other than language institutes, for instance in junior high school, high school, and university. It is recommended that future studies add more variables such as culture, social class, family background, IQ, EQ. 


\section{A COMPARATIVE AND ANAIYTIC COMPARISON OF THE VARIOUS IMAGES OF MOON AND THE SUN BASED ON ANCIENT ASTRONOMY IN NASER KHOSRO, ANVARI AND NEZAMI'S POEMS}

\section{References}

Bialystok, E. (1981). The role of conscious strategies in second language proficiency. The Modern Language Journal, 65(1), 24-35.

Carson, J. G., \& Longhini, A. (2002). Focusing on learning styles and strategies: A diary study in an immersion setting. Language learning, 52(2), 401-438.

Chamot, A. U., \& Kupper, L. (1989). Learning strategies in foreign language instruction. Foreign language annals, 22(1), 13-22.

Christison, M.A. (2003). Learning styles and strategies. In: Nunan, D. (Ed.), Practical English

Language

Teaching. McGraw-Hill, New York, pp.267- 288.

Dörnyei, Z. (2001). New themes and approaches in second language motivation research. Annual review of applied linguistics, 21, 43-59.

Dörnyei, Z. (2003). Attitudes, orientations, and motivations in language learning: Advances in theory, research, and applications. Language learning, 53(S1), 3-32.

Dörnyei, Z. (2005). The psychology of the language learner individual differences in second language acquisition. New Jersey: Lawrence Elbaum Associates.

Dunn, R., Beaudry, J., \& Klavas, A.(1989). Survey of research on learning styles. Educational leadership, 7, 50-5.

Ehrman, M., \& Oxford, R. (1990). Adult language learning styles and strategies in an intensive training setting. The modern language journal, 74(3), 311-327.

Ehrman, M. E., Leaver, B. L., \& Oxford, R. L. (2003). A brief overview of individual differences in second language learning. System, 31(3), 313-330.

Green, J. M., \& Oxford, R. (1995). A closer look at learning strategies, L2 proficiency, and gender. TESOL quarterly, 29(2), 261-297.

Heider, F. (1958). The psychology of interpersonal relations. New York: Wiley. Green, J. M., \& Oxford, R. (1995). A closer look at learning strategies, L2 proficiency, and gender. TESOL quarterly, 29(2), 261-297.

Heikkinen, A. (1999). A discourse analysis of success and failure accounts in learning English as a foreign language (Unpublished MA thesis). University of Jyväskylä, Finland.

Retrieved from http://selene.lib.jyu.fi:8080/gradu/g/1570.pdf

Hsieh, P. H. P., \& Schallert, D. L. (2008). Implications from self-efficacy and attribution theories for an understanding of undergraduates' motivation in a foreign language course. Contemporary Educational Psychology, 33(4), 513-532.

Kalaja, P. (2004). So maybe Freddie (Mercury) and his band mates really are to blame": Explaining success (or failure) in learning EFL. Future perspectives in foreign language education, 123-132.

Kinsella, K. (1995). Understanding and empowering diverse learners in ESL classrooms. Learning styles in the ESL/EFL classroom, 170-194.

O'malley, J. M., \& Chamot, A. U. (1990). Learning strategies in second language acquisition. Cambridge university press. 


\section{A COMPARATIVE AND ANAIYTIC COMPARISON OF THE VARIOUS IMAGES OF MOON AND THE SUN BASED ON ANCIENT ASTRONOMY IN NASER KHOSRO, ANVARI AND NEZAMI'S POEMS}

Oxford, R. L. (1990). Language learning strategies. NY: Harper-Row/Newbury House.

Oxford, R., \& Nyikos, M. (1989). Variables affecting choice of language learning strategies by university students. The modern language journal, 73(3), 291-300.

Oxford, R. L., \& Anderson, N. J. (1995). A crosscultural view of learning styles. Language teaching, 28(4), 201215.

Peacock, M., \& Ho, B. (2003). Student language learning strategies across eight disciplines. International Journal of Applied Linguistics, 13(2), 179-200.

Pishghadam, R., \& Modarresi, G. (2008). The Construct Validation and Application of a Questionnaire of. Iranian Journal of Language Studies-IJLS, 2.

Reid, J. M. (1987). The learning style preferences of ESL students. TESOL quarterly, 21(1), 87-111.

Reid, J. M. (1995). Learning styles in the ESL/EFL classroom. Heinle \& Heinle Publishers, International Thomson Publishing Book Distribution Center, 7625 Empire Drive, Florence, KY 41042.

Schreiber, J. B., Nora, A., Stage, F. K., Barlow, E. A., \& King, J. (2006). Reporting structural equation modeling and confirmatory factor analysis results: A review. The Journal of educational research, 99(6), 323-338.

Tse, L. (2000). Student perceptions of foreign language study: A qualitative analysis of foreign language autobiographies. The Modern Language Journal, 84, 69-84.

Weiner, B. (1974). Achievement motivation and attribution theory. Morristown, N.J.: General Learning Press.

Weiner, B. (1986). An attributional theory of motivation and emotion. New York: Springer-Verlag.

Weiner, I. B., \& Craighead, W. E. (2010). Attribution theory. The Corsini Encyclopedia of Psychology, Vol. 1, (4th ed), (pp. 184-186). New Jersey: John Wiley \& Sons.

Williams, M., \& Burden, R. L. (1997). Psychology for language teachers: A social constructivist approach. Cambridge: Cambridge University Press.

Williams, M., Burden, R. L., \& Al-Baharna, S. (2001). The role of the individual in motivation theory. Motivation and second language acquisition, 23, 171.

Williams, M., Burden, R., Poulet, G., \& Maun, I. (2004). Learners' perceptions of their successes and failures in foreign language learning. Language Learning Journal, 30, 19-29.

Willing, K. (1994). Learning Strategies in Adult Migrant Education. National Centre for English Language Teaching and Research, Sydney.

Wintergerst, A. C., DeCapua, A., \& Itzen, R. C. (2001). The construct validity of one learning styles instrument. System, 29(3), 385-403.

\footnotetext{
Contact details of the authors

Khalil Motallebzadeh

Department of English, Torbat-e Heydarieh Branch, Islamic Azad University, Torbat-e Heydarieh, Iran

*Maryam Ebrahimi Seresht (Corresponding author)
} 


\section{A COMPARATIVE AND ANAIYTIC COMPARISON OF THE VARIOUS IMAGES OF MOON AND THE SUN BASED ON ANCIENT ASTRONOMY IN NASER KHOSRO, ANVARI AND NEZAMI'S POEMS}

Department of English, Torbat-e Heydarieh Branch, Islamic Azad University, Torbat-e Heydarieh, Iran Email:

Samaneh Ardalan Javan

Department of English, Torbat-e Heydarieh Branch, Islamic Azad University, Torbat-e Heydarieh, Iran 